
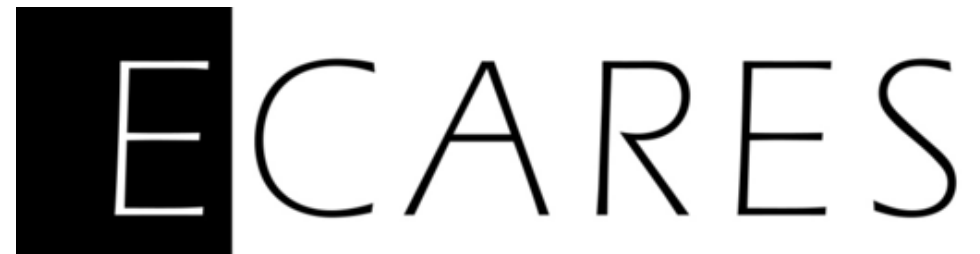

Productive Government Purchases and the Real Exchange Rate

Robert Kollmann

ECARES, Université Libre de Bruxelles, Université de Paris XII and CEPR

Parantap Basu

Durham University

ECARES working paper 2010-001 


\title{
Productive Government Purchases and the Real Exchange Rate
}

\author{
Parantap Basu ${ }^{\text {a }}$ \\ Robert Kollmann b,c,d,*
}

a Department of Economics and Finance, Durham University, 23/26 Old Elvet, Durham DH1 3HY, UK

b ECARES, Université Libre de Bruxelles, CP 114, 50 Av. Roosevelt, B-1050 Brussels, Belgium

c Faculté de Sciences Economiques, Université Paris XII, 61 Av. du Général de Gaulle, 94000 Créteil, France

d CEPR, 53-55 Great Sutton Street, London EC1V ODG, UK

December 8, 2009

Empirical research documents that an exogenous rise in government purchases in a given country triggers a depreciation of its real exchange rate. This raises an important puzzle, as standard macro theories predict an appreciation of the real exchange rate. We argue that this prediction reflects the assumption that government purchases are unproductive. Using a simple model, we show that the real exchange rate may depreciate in response to a rise in government purchases, if those purchases increase domestic private sector productivity. A very small dose of public sector externality is sufficient to generate this result.

JEL codes: F41, F42, E62.

Keywords: productive government purchases, real exchange rate.

\footnotetext{
* Corresponding author: Prof. R. Kollmann, ECARES, ULB, CP 114, 50 Av. Roosevelt, B-1050 Brussels, Belgium.

E-mail: robert_kollmann@yahoo.com,parantap.basu@durham.ac.uk

We thank Harris Dellas for useful discussions. R. Kollmann gratefully acknowledges financial support from the EU Commission.
} 


\section{Introduction}

A key prediction of standard open-economy models (e.g. Backus et al. (1994)) is that a country-specific rise in government purchases appreciates the real exchange rate. In those models, a rise in home government spending has a negative wealth effect that induces home households to work harder (which raises home output), and to consume less. The consequent rise in the home marginal utility of consumption has to be accompanied by an appreciation of the home real exchange rate, if consumption risk is efficiently shared internationally.

Much recent empirical research (based on structural vector-autoregressions) has, however, documented that an exogenous increase in government purchases in a given country triggers a depreciation of its real exchange rate (while domestic employment and output increase); see, e.g., Kollmann (1998), Dellas et al. (2005), Ravn et al. (2007) and Kim and Roubini (2008). This raises an important puzzle.

We argue that the real exchange rate appreciation predicted by standard theories reflects the assumption that government purchases are unproductive. Using a simple model, we show that the real exchange rate may depreciate in response to a rise in government purchases, if those purchases increase domestic private sector productivity. Aschauer (1989), Barro (1990), Basu (2001) and Bom and Ligthart (2009) stress the productive effects of government purchases. Intuitively, a rise in productive home government purchases triggers a larger increase in home output (than a rise in unproductive purchases). If this supply-side effect is strong enough, then the home terms of trade worsen, and the home real exchange rate depreciates. Our results suggest that a very small dose of public sector externality is sufficient to generate this effect.

\section{The Model}

\subsection{Environment}

There are two countries, Home $(\mathrm{H})$ and Foreign $(\mathrm{F})$. Each country is inhabited by a representative household and a government. Country $i=\mathrm{H}, \mathrm{F}$ produces $Y_{i}$ units of a tradable intermediate good $i$, using local labor $L_{i}$. The country's government levies a lump-sum tax to finance stochastic exogenous final good purchases $G_{i}$ that (potentially) raise labor productivity. The intermediate good production function is 


$$
Y_{i}=L_{i} G_{i}^{\theta} \text {, with } \theta \geq 0 .
$$

The introduction of $G_{i}$ in the production function is motivated by Barro (1990). Examples of public goods that raise private output include infrastructure facilities, and police protection to enforce property rights. The parameter $\theta$ represents the degree of public good externality.

Country $i$ also produces a non-traded final good $Z_{i}$ from local and imported intermediate inputs. The final good is used for private and government consumption. i's final-good production function is

$$
Z_{i}=\left[\alpha^{1 / \phi}\left(y_{i}^{i}\right)^{(\phi-1) / \phi}+(1-\alpha)^{1 / \phi}\left(y_{j}^{i}\right)^{(\phi-1) / \phi}\right]^{\phi /(\phi-1)} \text { with } j \neq i,
$$

where $y_{j}^{i}$ is the amount of intermediate good $j$ used in the production of final good $i ; \phi>0$ is the substitution elasticity between inputs. We assume $0.5<\alpha<1$, i.e. there is a bias in favor of the use of the local input.

Country i's technologies are operated by competitive firms owned by the local household. The labor market is likewise competitive. Prices thus equal marginal costs. The price of the country $i$ intermediate good, $p_{i}$, is hence $p_{i}=W_{i} G^{-\theta}$ where $W_{i}$ is the country $i$ wage rate. The price of the country $i$ final good is:

$$
P_{i} \equiv\left[\alpha\left(p_{i}\right)^{1-\phi}+(1-\alpha)\left(p_{j}\right)^{(1-\phi)}\right]^{1 /(1-\phi)}, \quad j \neq i .
$$

Profit maximization by final good firms implies these demand functions for intermediates:

$$
y_{i}^{i}=\alpha\left(p_{i} / P_{i}\right)^{-\phi} Z_{i}, y_{j}^{i}=(1-\alpha)\left(p_{j} / P_{i}\right)^{-\phi} Z_{i} \text { for } j \neq i .
$$

The country $i$ household has utility function $U_{i}=\frac{1}{1-\sigma}\left\{\left(C_{i}\right)^{1-\sigma}-1\right\}-\frac{1}{1+1 / \eta}\left(L_{i}\right)^{1+1 / \eta}$, where $C_{i}$ is private consumption. $\sigma, \eta>0$ are the risk aversion coefficient and the (Frisch) labor supply elasticity, respectively. The household equates her marginal rate of substitution between consumption and leisure to the real wage rate, $W_{i} / P_{i}$. Hence,

$$
C_{i}^{-\sigma} \frac{p_{i}}{P_{i}} G_{i}^{\theta}=L_{i}^{1 / \eta}
$$

Market clearing requires $Y_{i}=y_{i}^{H}+y_{i}^{F}$ and $Z_{i}=C_{i}+G_{i}$ for $i=\mathrm{H}, \mathrm{F}$. The Home terms of trade are $q \equiv p_{H} / p_{F}$; we define the Home real exchange rate as the price of final good $\mathrm{H}$ in units of 
final good $\mathrm{F}$ : $r e r \equiv P_{H} / P_{F}$; thus, a rise in rer is an appreciation of the Home real exchange rate.

Before government purchases are realized, the households trade in a complete set of Arrow-Debreu securities. In equilibrium, the ratio of Home to Foreign households' marginal utilities of final consumption is hence proportional to the real exchange rate (Kollmann (1991), Backus and Smith (1993)):

$$
\left(C_{H}\right)^{-\sigma} /\left(C_{F}\right)^{-\sigma}=\text { rer. }
$$

\subsection{Model Solution}

We assume that the distributions of government purchases are symmetric across countries, and denote mean government purchases by $\bar{G} \equiv E\left(G_{i}\right)$. We linearize the model around the equilibrium that obtains when $G_{H}=G_{F}=\bar{G} . \quad \hat{x} \equiv(x-\bar{x}) / \bar{x}$ is the relative deviation of a variable $x$ from the point of linearization, $\bar{x}$. Variables without subscripts are ratios of Home to Foreign variables: $y \equiv Y_{H} / Y_{F}, C \equiv C_{H} / C_{F}, g \equiv G_{H} / G_{F}$. (3) implies:

$$
\widehat{\operatorname{rer}}=(2 \alpha-1) \hat{q} \text {. }
$$

Thus, a Home terms of trade improvement induces a real exchange rate appreciation (as $\alpha>0.5$ ).

(4) implies that relative world demand for intermediate good $\mathrm{H}$ (compared to demand for good F) is: $d \equiv \frac{y_{H}^{H}+y_{H}^{F}}{y_{F}^{H}+y_{F}^{F}}=q^{-\phi} \frac{\alpha \operatorname{rer}^{\phi} z+1-\alpha}{\alpha+(1-\alpha) \operatorname{rer}^{\phi} z}$, where $z \equiv Z_{H} / Z_{F}=\left(C_{H}+G_{H}\right) /\left(C_{F}+G_{F}\right)$. Market clearing requires that relative demand equals relative output: $d=y$. This implies:

$$
\hat{y}=-\lambda \hat{q}+(2 \alpha-1) \Gamma \hat{g}
$$

where $\lambda \equiv 4 \alpha(1-\alpha) \phi+(2 \alpha-1)^{2}(1-\Gamma) / \sigma>0$ is the elasticity of relative world demand for the Home intermediate good with respect to the Home terms of trade, with $\Gamma \equiv \overline{G_{i}} /\left(\overline{C_{i}}+\overline{G_{i}}\right) .{ }^{1}$

(8) is an 'effective' relative demand function for the Home intermediate good. Relative demand is decreasing in the Home terms of trade. Holding constant the terms of trade, an

\footnotetext{
${ }^{1}$ To obtain (8), we use $\hat{z}=(1-\Gamma) \hat{c}+\Gamma \hat{g}$ and $\hat{c}=-\sigma^{-1}(2 \alpha-1) \hat{q} \quad$ (from (6), (7)).
} 
increase in Home relative government purchases raises relative demand for the Home good (as $\alpha>0.5)$.

The optimal consumption/leisure trade-off (5) and the risk sharing condition (6) imply $\hat{l}=\eta \hat{q}+\eta \theta \hat{g}$, where $l \equiv L_{H} / L_{F}$ is the relative country $\mathrm{H}$ labor input. The production function (1) implies $\hat{y}=\hat{l}+\theta \hat{g}$. Thus:

$$
\hat{y}=\eta \hat{q}+(1+\eta) \theta \hat{g}
$$

(9) is a relative supply function of Home intermediates. A Home terms of trade appreciation raises the relative Home supply (the terms of trade improvement raises the Home marginal product of labor, in units of final consumption, which increases the Home labor supply). Holding constant $q$, a rise in Home government purchases raises the relative supply of Home intermediates, if government purchases are productive, $\theta>0$.

(8) and (9) can be solved for the equilibrium real exchange rate:

$$
\widehat{\operatorname{rer}}=\Psi \widehat{g}, \quad \text { with } \Psi \equiv(2 \alpha-1)\{(2 \alpha-1) \Gamma-(1+\eta) \theta\} /(\lambda+\eta)
$$

When government purchases are unproductive $(\theta=0)$ then $\Psi>0$, i.e. a rise in (relative) Home government purchases appreciates the Home real exchange rate. Intuitively, a rise in Home government purchases raises the relative demand for the Home intermediate goods (see above). When $\theta=0$, the rise in government purchases does not affect the (relative) supply schedule of Home intermediates; thus, the rise in demand improves the Home terms of trade, and the Home real exchange rate appreciates.

When government purchases are productive $(\theta>0)$ then a rise in (relative) Home government purchases shifts up the (relative) supply schedule of Home intermediates (9), which mitigates the terms of trade improvement. When $\theta$ is sufficiently big, this supply effect dominates and the real exchange rate depreciates; specifically, this is the case when $(1+\eta) \theta>(2 \alpha-1) \Gamma$.

\section{Model calibration}

Our calibration closely follows the international macro literature (e.g. Kollmann (1996)). In typical industrialized economies, government spending and imports are both about $20 \%$ of GDP. We thus set $\Gamma=0.2$ and $\alpha=0.8$. We set the labor supply elasticity, the risk aversion 
coefficient and the substitution elasticity between domestic and foreign intermediate goods at $\eta=2, \sigma=2$ and $\phi=1.5$, respectively; those parameter values are well in the range of empirical parameter estimates, for industrialized countries (see Coeurdacier, Kollmann and Martin (2008) for a detailed justification). For these parameter values, the government purchases externality $\theta$ has to just exceed 0.04 for a rise in government purchase to depreciate the real exchange rate.

The Table reports the responses of the real exchange rate, and of relative Home output, labor supply and consumption to a $5 \%$ increase in Home government purchases (that rise in $G_{H}$ amounts to $1 \%$ of Home GDP in the absence of the shock). When $\theta=0$, the Home real exchange rate appreciates by $0.12 \%$; Home relative output and employment rise by $0.39 \%$, while Home relative consumption declines by $0.06 \%$. Larger values of $\theta$ strengthen the response of Home relative output, and induce a rise in Home relative consumption. E.g., when $\theta=0.2$, the shock to Home government purchases depreciates the real exchange rate by $0.46 \%$ and raises (relative) output and consumption by $1.45 \%$ and $0.23 \%$, respectively.

\section{Responses (in \%) to $5 \%$ increase in Home government purchases}

\begin{tabular}{|l|l|l|l|l|}
\hline$\theta$ & $\wedge$ & $\hat{y}$ & $\hat{l}$ & $\hat{c}$ \\
\hline 0 & 0.12 & 0.39 & 0.39 & -0.06 \\
\hline 0.1 & -0.17 & 0.92 & 0.42 & 0.09 \\
\hline 0.2 & -0.46 & 1.45 & 0.45 & 0.23 \\
\hline 0.3 & -0.75 & 1.99 & 0.49 & 0.38 \\
\hline
\end{tabular}

Note--For the values of $\theta$ (output elasticity of the public good) listed in Column 1, the Tables reports responses (in \%) of the Home real exchange rate (rer), and of relative Home output (y), hours worked (l) and consumption (c), to a shock that increases Home government purchases by $5 \%$ (i.e. by $1 \%$ of no-shock GDP).

What is an empirically plausible value of the output elasticity of government purchases, $\theta$ ? A considerable literature exists on the estimation of the elasticity of output with respect to public capital. Using a production function approach, Aschauer (1989) estimates this elasticity at about 0.39 . Using a meta analysis based on 67 empirical studies, Bom and Lightart (2009) derive an output elasticity of 0.146. In our calibration, the threshold level of $\theta$ is only 0.04 , which is lower than these empirical estimates. The bottom-line is that for a plausible public sector externality, an increase in government purchase depreciates the real exchange rate. 


\section{Conclusion}

This paper has shown that a neoclassical model has the potential to explain why (as suggested by empirical research) a rise in government purchases triggers a real exchange rate depreciation. The key ingredient of the model here is the assumption that government purchases raise private sector productivity. A very small dose of public sector externality is sufficient to generate this result. 


\section{References}

Aschauer, D, 1989, Is Public Expenditure Productive? Journal of Monetary Economics 23, 177-282.

Backus, D., and G. Smith, 1993, Consumption and Real Exchange Rates in Dynamic Economies with Non-traded Goods, Journal of International Economics 35, 297-316.

Backus, D., P. Kehoe and F. Kydland, 1994, Dynamics of the Trade Balance and the Terms of Trade: the J-Curve? American Economic Review 84, 84-103.

Barro, R., 1990, Government Spending in a Simple Model of Endogenous Growth, Journal of Political Economy 98, S103-S125.

Basu, P., 2001, Reserve Ratio, Seigniorage and Growth, Journal of Macroeconomics 23, 397-416.

Bom, P. and J. Ligthart, 2009, What Have We Learned From the Three Decades of Research on the Productivity of Public Capital? Tilburg University Working Paper.

Coeurdacier, N., R. Kollmann and P. Martin, 2008, International Portfolios With Supply, Demand and Redistributive Shocks, NBER International Seminar on Macroeconomics 2007, 231-263.

Dellas, H., K. Neusser and M. Wältli, 2005, Fiscal Policy in Open Economies, Working Paper, University of Bern.

Kim, S. and N. Roubini, 2008, Twin Deficits or Twin Divergence? Fiscal Policy, Current Account, and Real Exchange Rate in the U.S., Journal of International Economics 74, 362-383.

Kollmann, R., 1991, Essays on International Business Cycles, PhD Dissertation, Economics Department, University of Chicago.

Kollmann, R., 1996, Incomplete Asset Markets and the Cross-Country Consumption Correlation Puzzle, Journal of Economic Dynamics and Control 20, 945-962.

Kollmann, R., 1998, Effects of Government Spending in Open Economies, Working Paper, University of Paris XII.

Ravn, M., S. Schmitt-Grohé and M. Uribe, 2007, Explaining the Effects of Government Spending Shocks on Consumption and the Real Exchange Rate, Working Paper 13328, National Bureau of Economic Research. 